\title{
Analysis of Scottish Seine Fishing Gear Operating in the waters of Majene West Sulawesi Province
}

\author{
Hardianti Nur ${ }^{1, *}$, Najamuddin ${ }^{2}$, Andi Assir Marimba ${ }^{2}$
}

\author{
${ }^{1}$ Student of Master Degree Fisheries Science, Faculty of Marine and Fisheries Science, Hasanuddin University, Perintis Kemerdekaan, \\ St.Km 10, Makassar 90245, Indonesia \\ ${ }^{2}$ Department of Fisheries Science, Faculty of Marine and Fisheries Science, Hasanuddin University, Perintis Kemerdekaan St Km 10 , \\ Makassar 90245, Indonesia \\ *Corresponding Author
}

\begin{abstract}
The purpose of this study is to evaluate Scottish Seine fishing gear and to analyze Scottish Seine fishing gear in technical and biological aspects in review based on the Minister of Marine Affairs and Fisheries Regulation No. 2 of 2015. The analysis used in this research is multiple linear regression analysis and analysis of the size of the first maturity of gonads. There are three types of fishing gear operating areas for the Scottish Seine in Majene waters, namely the Scottish Seine which is operated in close FADs, medium FADs and long FADs. The results obtained were that one of the fish caught was sortfin scad fish which produced a fish that was fit to be caught. However, the catch of the three FADs' Scottish Seine fishing gear was predominantly unfit for catching fish. Scottish Seine fishing gear in Majene waters is in accordance with the regulation Minister of Marine Affairs and Fisheries Regulation No. 2 of 2015 produce fish catches that are not suitable to be caught. The use of FADs which causes the catch of Scottish Seine fishing gear to produce fish that are not suitable to be caught, and the use of a relatively small mesh size of the Scottish Seine fishing gear.
\end{abstract}

Keywords-Technical And Biological Aspects, Scottish Seine Fishing Gear, Sustainable Fishing

\section{INTRODUCTION}

The attention of the Government of Indonesia towards sustainable capture fisheries management continues to be increased. One of the most interesting is the issuance of Minister of Marine Affairs and Fisheries Regulation No. 2 of 2015 concerning the prohibition of using Trawls and Seine nets in the Fisheries Management Area of the Republic of Indonesia. 2 of 2015 concerning the prohibition of using Scottish Seine fishing gear is resulting in a decrease in fish resources and threatens the environmental sustainability of fish resources. Panggabean et al, (2016). One area that uses the Scottish Seine's fishing gear a lot is Majene District. Scottish Seine is the dominant pelagic fishing gear in Majene Regency. This tool is a traditional fishing tool that has been passed down from generation to generation.

While the results of Ulpa (2006) study in Majene waters on the Scottish Seine fishing gear found that the dominant fish caught, namely sortfin scad fish showed that the size of the catch of sortfin scad fish was $200 \mathrm{~mm}$ for the first time. According to Dahlan (2015) states that sortfin scad fish the size of the first time to spawn was $195 \mathrm{~mm}$, so that it is based on the size of fish fit to be caught in Majene waters on the Scottish Seine fishing gear, which is to produce catchable fish. Then based on several observations in the field that the problems between Scottish Seine fishing gear in other water areas have differences according to their characteristics, several previous studies, one of which is Simbolon (2011) at the port of Ratu, stated that the Scottish Seine fishing gear has a mesh size that is relatively small compared to the target catch (fit to be caught) so that the results obtained at the size of the fish catch are not producing fish that are fit to be caught. Then Sutono (2016) in the coastal waters of Tegal, the Scottish Seine fishing operation is carried out near the coast within 1 - 2 miles, the results show that the fish caught are predominantly small fish (unfit to catch) this can cause fish resources to decline due to fishing exaggerated. 
Seeing the difference in the size of the fish catch in the Scottish Seine fishing gear in the territory of Indonesia, a study was carried out on the use of the Scottish Seine fishing gear, especially in the waters of Majene Regency by looking at several aspects, namely technical and biological aspects, so that the sustainability of the Scottish Seine fishing gear was carried out. especially in the area of Majene Regency, West Sulawesi. The purpose of this study is to evaluate the Scottish Seine fishing gear in a review of the Ministry of Marine Affairs and Fisheries Regulation No. 2 of 2015 and to analyze the technical and biological aspects of Scottish Seine fishing gear in Majene waters, West Sulawesi.

\section{RESEARCH METHODS}

This research was conducted in the waters of Majene Regency, West Sulawesi, to be precise in Pangaliali Village, Majene Harbor. The research was carried out in May - November 2019. The method used in the study was the census method of all Scottish Seine fishing gear populations, and measurement of fish catches. Data was collected by following fishing operations for 30 fishing trips of far, medium and near FADs. Measurement of the catch was carried out by using a stratified random sampling method of 1,170 sortfin scad fish observation was carried out by measuring the length and weight of the fish and looking at the sex and gonad maturity of the fish, measuring the total length of the fish using a ruler with the smallest scale of $1 \mathrm{~mm}$. The required data was obtained after the ship landed its catch at fish auction Pangaliali waters, Majene Regency.

\section{A. Data Analysis}

1. Technical Aspects

Data analysis carried out in this study was processed using the Multiple Linear Regression Analysis Model, which is to determine the effect of fish catch size, the independent variable $(\mathrm{X})$ is the mesh size of the bag (close FAD, medium FAD and far FAD) dependent variable (Y) size of fish catch.

\section{Biological Aspects}

Measurements of the parameters of the biological aspects in this study are to determine the length and weight of the catch of sortfin scad fish on the Scottish Seine fishing gear operating in Majene waters, the measurement of the fish is carried out every day from May to November. The size of the fish that is fit to catch is the size of the fish that the gonads ripen the first time. This is to determine the categories of biologically fit and unfit for fishing. The basis used to determine the maturity level of the gonads is, among others, the observation of macroscopic morphological features, namely shape, length, weight, color and development of gonad contents. The criteria for the level of gonad maturity used the Cassie method modified by Effendie (1997). The estimation of the size of the first maturity of gonads was analyzed using the Sperman-Karber method (Udupa, 1986) as follows:

$$
\log m=X_{k}+\frac{X_{i}}{2}-\left(X \sum p_{i}\right)
$$

Where:

$\mathrm{Xk}=$ logarithm of the last mean value when the fish is $100 \%$ cooked;

$\mathrm{X}=$ the average difference in the logarithms of the mean class;

$\mathrm{Xi}=\log$ arithm of the mean class value;

pi = ri / ni; ri = number of cooked gonad fish in class $i$;

$\mathrm{ni}=$ number of fish in class $\mathrm{i} ; \mathrm{qi}=1-\mathrm{pi}$

Variety $=X^{2} \sum\left[\frac{p i^{*} q i}{n i-1}\right]$ Interval 95\%: $m \pm Z_{\alpha / 2} \sqrt{\text { Variety }}$

In principle, this method is in line with the sigmoid curve method, only in this method the size range is calculated mathematically, so that it is more convincing in determining the reference size. The criteria for gonad maturity are at gonad maturity 3, 4 and 5. (Najamuddin 2004).

\section{RESULTS \& DISCUSSION}

\section{Technical Aspects of Catching Scottish Seine}

The percentage of the independent variables of the mesh size of the finger bags of FADs near FAD, medium FAD, far and $(\mathrm{X})$ to the dependent variable fish catch size (Y) can be seen from the value of the coefficient of determination (R2). From the SPSS output table, it can be seen that the R-Square (R2) value of the regression model formed in this study is 0.581. The coefficient of determination R Square (R2) is 0.170 , which means that $17 \%$ of the catch size is caused by the variable mesh size of the fishing gear bag of close FADs, medium FAD and far FAD and the rest is influenced by other factors.

Based on the results of the F test, it was found that the pvalue $\mathrm{F}$ was 0,000 . Therefore, the $\mathrm{p}$-value $\mathrm{F}$ is $0.000<0.05$, so the regression equation can be accepted which means that the mesh size of fishing gear bags used at near, medium FADs, and far FADs together have a significant effect on the size of fish catch. 


\begin{tabular}{|c|c|c|c|c|c|}
\hline \multirow[b]{2}{*}{ Model } & \multicolumn{2}{|c|}{$\begin{array}{l}\text { Unstandardized } \\
\text { Coefficients }\end{array}$} & \multirow{2}{*}{$\begin{array}{l}\text { Standardiz } \\
\text { ed } \\
\text { Coefficient } \\
\text { s } \\
\text { Beta }\end{array}$} & \multirow[b]{2}{*}{$\mathrm{T}$} & \multirow[b]{2}{*}{ Sig. } \\
\hline & B & $\begin{array}{l}\text { Std. } \\
\text { Error }\end{array}$ & & & \\
\hline (Constant & $\begin{array}{r}- \\
1.327\end{array}$ & 10.048 & & -.132 & .896 \\
\hline Near & $\begin{array}{r}17.01 \\
0\end{array}$ & 11.117 & .310 & 1.530 & .010 \\
\hline Medium & $\begin{array}{r}14.09 \\
6\end{array}$ & 10.600 & .279 & 1.330 & .019 \\
\hline Far & 1.214 & 14.978 & .017 & .081 & .130 \\
\hline
\end{tabular}

From the regression model above, the best regression model is obtained, based on the significance value (independent variable), namely the close coefficient of FADs (X1) 17.010 and medium FADs (X2) is positive and it can be concluded that if the addition of the mesh size of the fishing gear bag of Scottish Seine is done, the catch the fish will get bigger. The effect of the size of the fish catch is also influenced by the location of the area where the fish is operated.

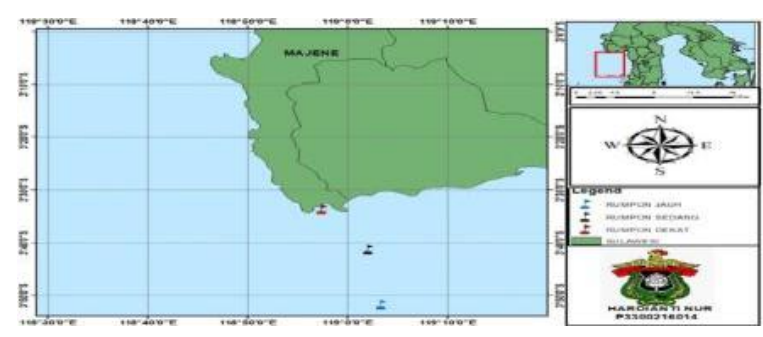

Fig 1. Fishing area

Based on research on the catching area for Scottish Seine fishing gear in Majene waters, the operation shows that the FADs close to operate the distance from the fishing base to the fishing ground, namely 1 - 2 miles, while the FADs are between the fishing base to the fishing ground $5-8$ mill and the remote FADs are 8 - 15 mill. Ministry of Marine and Fishery decision Number 71 concerning fishing routes in 2016 states that Scottish Seine fishing gear can catch fish within a distance of $>4$ nautical miles. (Deri et al 2019).

\section{Biological Aspect Analysis}

A total of 1,170 scortfin scad fish in Majene waters were measured and observed, consisting of 669 males and 504 females. The results of calculations with a $95 \%$ confidence interval showed that sortfin scad fish males first matured the gonads at a fork length of $145 \mathrm{~mm}$ with a length range of 14.36-15.60 cm. sortfin scad fish mature female gonads with a fork length of $170 \mathrm{~mm}$ with a $95 \%$ confidence range between $17.18-18.91 \mathrm{~cm}$.

Table 1. Frequency of fork length (cm) and length calculation for the first maturity of male gonads sortfin scad fish (Deapterrus macrosoma)

\begin{tabular}{|c|c|c|c|c|l|}
\hline \multirow{2}{*}{ Class hose } & $\begin{array}{l}\text { Middl } \\
\text { e } \\
\text { Value }\end{array}$ & $\begin{array}{c}\text { Middl } \\
\text { Value } \\
\text { Log }\end{array}$ & $\begin{array}{c}\text { Numbe } \\
\text { Of } \\
\text { Fish }\end{array}$ & $\begin{array}{c}\text { Mat } \\
\text { ure }\end{array}$ & $\begin{array}{l}\text { Pi*Qi } \\
\text { /Ni-1 }\end{array}$ \\
\cline { 2 - 5 } & Nt & Xi & Ni & Nb & \\
\hline $145-150$ & 148 & 2,170 & 29 & 0 & 0 \\
\hline $150-155$ & 153 & 2,184 & 40 & 0 & 0 \\
\hline $160-165$ & 163 & 2,212 & 35 & 0 & 0 \\
\hline $165-170$ & 168 & 2,225 & 14 & 2 & 0,009 \\
\hline $170-175$ & 173 & 2,238 & 38 & 6 & 0,006 \\
\hline $175-180$ & 178 & 2,250 & 17 & 5 & 0,012 \\
\hline $180-185$ & 183 & 2,262 & 22 & 10 & 0,011 \\
\hline $185-190$ & 188 & 2,274 & 39 & 12 & 0,005 \\
\hline $190-195$ & 193 & 2,285 & 49 & 19 & 11,39 \\
\hline $195-200$ & 198 & 2,296 & 61 & 44 & 12,48 \\
\hline $200-210$ & 207 & 2,315 & 126 & 80 & 28,40 \\
\hline $210-215$ & 213 & 2,328 & 76 & 66 & 8,569 \\
\hline $220-225$ & 223 & 2,348 & 61 & 50 & 7,546 \\
\hline $230-235$ & 234 & 2,369 & 48 & 42 & 5,140 \\
\hline $235-240$ & 238 & 2,376 & 14 & 12 & 1,591 \\
\hline $240-245$ & 243 & 2,385 & 0 & 0 & 0 \\
\hline $245-250$ & 248 & 2,394 & 0 & 0 & 0 \\
\hline Total & & & 669 & 331 & 75,17 \\
\hline
\end{tabular}


Table 2. Frequency of fork length $(\mathrm{cm})$ and length calculation for the first maturity of female gonads sortfin scad fish (Decapterrus macrosoma)

\begin{tabular}{|c|c|c|c|c|l|}
\hline \multirow{2}{*}{ Class hose } & $\begin{array}{l}\text { Middl } \\
\text { e } \\
\text { Value }\end{array}$ & $\begin{array}{c}\text { Middl } \\
\text { Value } \\
\text { Log }\end{array}$ & $\begin{array}{c}\text { Numbe } \\
\mathrm{r} \\
\text { Of } \\
\text { Fish }\end{array}$ & $\begin{array}{c}\text { Matur } \\
\text { e }\end{array}$ & $\begin{array}{l}\text { Pi*Qi } \\
\text { /Ni-1 }\end{array}$ \\
\hline $145-150$ & 148 & 2,170 & 20 & 0 & 0 \\
\hline $150-155$ & 153 & 2,184 & 8 & 0 & 0 \\
\hline $160-165$ & 163 & 2,212 & 28 & 0 & 0 \\
\hline $165-170$ & 168 & 2,225 & 17 & 0 & 0 \\
\hline $170-175$ & 173 & 2,238 & 22 & 0 & 0 \\
\hline $175-180$ & 178 & 2,250 & 33 & 6 & 0,013 \\
\hline $180-185$ & 183 & 2,262 & 10 & 2 & 0,017 \\
\hline $185-190$ & 188 & 2,274 & 32 & 7 & 0,005 \\
\hline $190-195$ & 193 & 2,285 & 18 & 9 & 0,014 \\
\hline $195-200$ & 198 & 2,296 & 21 & 8 & 0,011 \\
\hline $200-210$ & 207 & 2,315 & 44 & 19 & 10,75 \\
\hline $210-215$ & 213 & 2,328 & 57 & 24 & 16,39 \\
\hline $220-225$ & 223 & 2,348 & 109 & 87 & 24,24 \\
\hline $230-235$ & 234 & 2,369 & 53 & 49 & 11,30 \\
\hline $235-240$ & 238 & 2,376 & 34 & 26 & 5,937 \\
\hline $240-245$ & 243 & 2,385 & 5 & 4 & 0,64 \\
\hline $245-250$ & 248 & 2,394 & 4 & 3 & 0,56 \\
\hline Total & & & 504 & 238 & 69,89 \\
\hline
\end{tabular}

The size distribution of male and female sortfin scad fish in Majene waters has the smallest size of $140 \mathrm{~mm}$ to the largest size of $250 \mathrm{~mm}$, the size of fish fit to be caught is in the male fish class interval 190-200 $\mathrm{mm}$ and the female class interval $210-220 \mathrm{~mm}$. Based on the observation data of male sortfin scad fish with fork length $<20.05 \mathrm{~mm}, 362$ of the total 659 male fish were observed, while 287 female kites with fork length $<21.01 \mathrm{~mm}$ were observed from a total of 504 female fish, namely immature gonads.

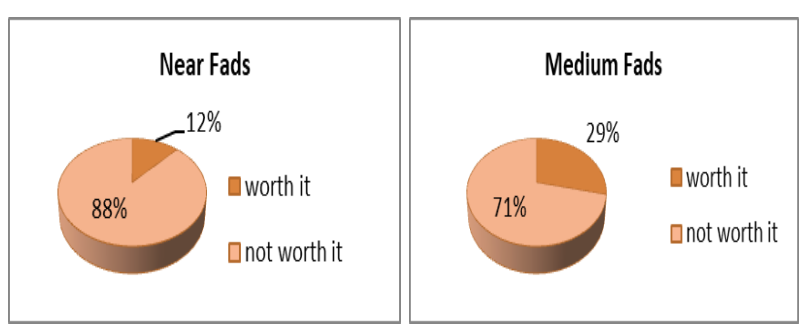

Fig 2. Percentage of FADs Fig 3. Percentage of FADs

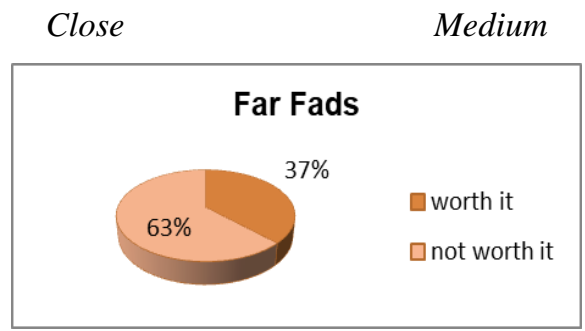

Fig 4. Percentage of distant FADs

The results showed that some sortfin scad fish caught in the FAD area were dominated by small fish (not yet fit to catch). Based on the figure, the percentage of catch size in Majene waters through the morphological approach in medium FAD was $29 \%$ feasible and not fit to catch by $71 \%$ while sortfin scad fish in distant FADs get a capture size of $37 \%$ and not fit to catch $63 \%$. The area of FAD close to get the size of fish that is fit to catch, as much as $12 \%$ of the percentage of fish size fit to be caught in the three FADs are dominated by fish that are not fit to be caught. The results of data analysis of the three FADs were the percentage of fishing that affected the use of FADs carried out. This is because the presence of FADs causes a lot of food around FADs (phytoplankton).

Based on the Ministry of Marine Affairs and Fisheries Decree No.2 of 2015 that the Scottish Seine fishing gear is prohibited for catching small fish, the use of mesh size nets in Majene waters needs to be enlarged to produce a catch size suitable for fishing and in accordance with the provisions of the Minister of Marine Affairs and Fisheries Decree No. 71 The 2016 Fishing Route for the operation of the Scottish Seine fishing gear can be used if the mesh size of the net sack is $>1 \mathrm{inch}$. This needs to be considered because if the size of the mesh used is not changed it will cause the fish resources in the waters to decrease, and the fish resources in coastal waters will be degraded to extinction. (Lorenzon 2016).

\section{CONCLUSION}

There are three types of fishing gear operating areas for the Scottish Seine in Majene waters, namely the Scottish Seine which is operated in close FADs, medium FADs and 
distant FADs. Based on the technical aspect, statistically the model is suitable for use with an accuracy of $>99 \%$. Biological aspects show that the catch is suitable for fishing, namely $200 \mathrm{~mm}$ male sortfin scad fish and 210 $\mathrm{mm}$ female sortfin scad fish however the catch of the three FADs is predominantly unfit for catching, so the Scottish Seine fishing gear in Majene waters is in accordance with the regulations Minister of Marine Affairs and Fisheries Regulation No. 2 of 2015, namely producing fish catches that are not fit to be caught. The use of FADs which resulted in the catch of the Scottish Seine's fishing gear produced unsuitable fish, and the use of the relatively small mesh size of the Scottish Seine's fishing gear, so it needed to be enlarged, using a mesh size $>1$ inch. This needs to be considered because if the size of the mesh used is not changed it will reduce the fish resources in Majene waters.

\section{REFERENCES}

[1] Dahlan, M. A., S.A. Omar, J. Tresnati, M.T. Umar \& M. Nur. 2015. Sex ratio and size of the first matured fish gonads of Deles (Decapterus Macrosoma Bleeker, 1841) in the waters of the Gulf of Bone, South Sulawesi. Makassar, May 2015. Torani (Journal of Marine and Fisheries Sciences). Vol. 25 (1) April 2020: 36-40. ISSN: 0853-4489

[2] Deri Novita, Desi Albert Mamahit, Yusnaldi 2019 Impact of Implementation of Minister of Marine Affairs and Fisheries Regulation Number 71 of 2016 on National Security (Case Study in West Sumatra Province) Maritime Security Study Program, Defense University (Maritime Security Journal) Vol. 5 No: 81 - 95

[3] Effendie, M.I. 1997. Fisheries Biology. Pustaka Nusatama Foundation. Yogyakarta. $163 \mathrm{p}$.

[4] Ermawati N, Zuliyati. 2015. Social and Economic Impacts of Minister of Marine Affairs and Fisheries Regulation Number 2 / 2015: A Case Study of Juwana District, Pati District. Journal Of Management Of Aquatic Resources. Vol 2 No (3) Page: 197-202.

[5] Farah Ulpa 2006. Composition of Scottish Seine Catch Types by Location of FADs in the Waters of Majene Regency, West Sulawesi. Thesis of Fisheries Resources Utilization, Faculty of Marine and Fisheries Sciences, Hasanuddin University Thesis

[6] Regulation of the Minister of Marine Affairs and Fisheries of the Republic of Indonesia Number PER.02 / MEN / 2015 concerning the Prohibition of Using Trawls and Seine Nets in the Fisheries Management Area of the Republic of Indonesia.

[7] Regulation of the Minister of Marine Affairs and Fisheries of the Republic of Indonesia Number 71 / Ministry of Marine and Fishery decision / 2016 concerning Fishing Routes and Placement of Fishing Tools in the Fisheries Management Area of the Republic of Indonesia
[8] Najamudin, Mallawa, A., Budimawan \& Indar, M.Y. 2004. Estimation of the Size of the First Ripe Fish Gonads of Deles (Decapterus Macrosoma Bleeker). Postgraduate Program. J Science and Technology, Faculty of Marine and Fisheries Sciences, Hasanudin University ,. Makassar. April 2004, Vol. 4 No. 1: 1-8. ISSN 1411-4674

[9] Lorenzen K. 2016 Toward a new paradigm for growth modeling in fisheries stock assesments: embracing plasticity and its consequences. Journal of Fisheries Research. 180 (1): 4-22.

[10] Panggabean, S. A, Suhaidi., Leviza, J, Barus, U. M. (2016). Implementation of Minister of Marine Affairs and Fisheries Regulation No. 2015 concerning the Prohibition of Using Trawls and Seine Nets on Capture Fisheries by Fishermen in Sibolga. USU Law Journal. 4 (4): 40-52

[11] Simbolon D. 2011. Bioecology and Dynamics of Fishing Areas. Bogor (ID). Department of Fisheries Resource Utilization, FPIK, IPB. Journal of Mangrove and Coastal. 10 (1): $42-49$

[12] Sutono and Adi Susanto 2016 Utilization of Scottish Seine Fishing Gear Resources in Tegal Beach Waters, Department of Fisheries, Faculty of Agriculture, Sultan Ageng Tirtayasa University Journal of Fisheries and Marine Affairs Volume 6 Number 2 Pages: $104-115$

[13] Udupa, K. S. 1986. Statistical Methods Of Estimating The Size At First Maturity In Fishes. Fishbyte, 4(2): 8-10. 